\title{
Chapter 10 \\ The Social and Solidarity Economy: Why Is It Relevant to Industrial Ecology?
}

\author{
Marlyne Sahakian
}

\begin{abstract}
One can no longer even imagine that there could be a single standard of value by which to measure things. The neoliberals (...) are singing the praises of a global market that is, in fact, the single greatest and most monolithic system of measurement ever created, a totalizing system that would subordinate everything - every object, every piece of land, every human capacity or relationship - on the planet to a single standard of value. - David Graeber (2001).
\end{abstract}

Toward an Anthropological Theory of Value:

The false coin of our own dreams, p. xi.

\begin{abstract}
The goal of this contribution is to illustrate the linkages between industrial ecology (IE) and the social and solidarity economy (SSE), an economic paradigm that is robust in terms of conceptual and historical developments, and active around the world as a social movement. The SSE includes a range of activities, such as fair trade, community currencies and some forms of peer-to-peer sharing, to name but a few. The links and tensions between SSE and IE are considered first conceptually, by uncovering the theoretical frameworks attached to each field. Three 'solidarity' practices are then discussed in relation to industrial ecology activities, namely: aspects of the sharing economy, community currencies and forms of crowd-funding. A main finding is that the two fields of research and practice are compatible, as neither focus on economic growth and specifically profit as an ultimate aim; yet IE prioritizes biophysical considerations, whereas the SSE places more emphasis on people and power systems, as expected. One insight gleaned through this process is that more attention could be placed on labour conditions, power relations and governance systems in industrial ecology, building on previous and ongoing work in this area.

Four main fields of inquiry emerge: understanding whether 'solidaristic' cooperatives and enterprises could be more receptive to industrial ecology approaches and more adept at embracing resource exchanges such as in industrial symbiosis; ascertaining to what extent companies already involved in symbiotic relations might
\end{abstract}

M. Sahakian $(\bowtie)$

Industrial Ecology Group, Faculty of Geosciences and the Environment,

University of Lausanne, Batiment Geopolis, CH-1015 Lausanne, Switzerland

e-mail: marlyne.sahakian@unil.ch 
also embody social and solidarity values, including notions of participative governance, limited profit-making, a focus on employee benefits, among others; considering certain forms of crowdfunding as an opportunity for abating economy-wide rebound effects through more socially just and environmentally sound investments; and finally, the potential for complementary currencies to work towards industrial ecology aims. One of the weaknesses of the social and solidarity economy has been that of scale, as SSE activities tend to take place on a micro-scale, with some notable exceptions. That being said, the SSE is well underway and expanding, in research and practice, presenting interesting synergies with IE and opportunities for further research and action. Bringing together IE and SSE ultimately brings to the fore a discussion around paradigms and associated values, including societal and environmental priorities which are not always aligned - raising questions around what values we wish to put forward in our economy, workplaces and society.

Keywords Community currencies • Crowd-funding • Reciprocity • Solidarity economy $\bullet$ Sharing economy

\section{Introduction}

In the past decade, a slew of terms have emerged to describe new economic models: the people-first or human economy (Ransom and Baird 2010; Hart et al. 2010), the new economy (Schor and Thompson 2014), the green economy (UNEP 2011), the sharing economy (Botsman and Rogers 2010; Gansky 2010), diverse economies (Gibson-Graham 2006; Gibson-Graham 2008) and the varying definitions of the circular economy (Yuan et al. 2006; Ellen MacArthur Foundation 2013), to name but a few. In some cases, these terms represent alternatives to the dominant market economy, understood here as being based on competition and private ownership; in most cases, what plays out in practice are economic activities that are at best complementary to and on the fringes of the market economy. Their emergence suggests a growing interest in finding new ways to engage in production, consumption, exchanges and financing, to better manage resources, and strive for greater prosperity than what is currently being achieved with the dominant economic model. More specifically, all of these approaches share the ambition of tackling the question of how economic systems can better serve - rather than be severed from - environmental or social aims. The goal of this contribution is to assess whether these models can bring new fields of reflection and action to the industrial ecology community.

One reason for this renewed interest in economic models is the heightened concern around recurring financial crises, the destabilization of natural cycles and widening inequalities. Particularly in times of economic depression, people look for alternative ways to access products and services, including financial services. In Switzerland in 1934, in the wake of the Great Depression and facing a credit crunch, 
a group of entrepreneurs created a new currency, the WIR, ${ }^{1}$ which continues to be exchanged today - notably during economic recessions, where this complementary currency may have a stabilizing effect on the national economy (Studer 2006). Since the 2008-2009 financial crisis in Greece, international press has covered the emergence of new forms of barter, where services and products are traded based on units of exchange ranging from time to community currencies (Poggioli 2011; Lowen 2012). New peer-to-peer models for sharing resources and services are also very much in the spotlight today, propelled by information technologies that have made sharing and bartering activities available on a wider scale and across different sectors. The sharing economy touts lofty goals, such community-building, economic empowerment, creative expression, but also better resource management. Whether these goals are achieved remains to be evaluated in practice, particularly in relation to environmental aims: the notion that 'sharing' could lead to reduced energy and material throughputs are still up for debate (Cohen 2014). Kalamar (2013) coined the termed 'share-washing' for attempts by 'business as usual' activities to claim such social goals.

In this chapter, the social and solidarity economy (SSE) will be considered, an economic paradigm that is robust in terms of conceptual and historical developments, but also active around the world as a social movement. The SSE includes a range of activities, such as fair trade, community currencies, peer-to-peer activities, cooperative and mutual organizations, some forms of sharing, to name but a few. This chapter introduces the social and solidarity economy (SSE) as a theoretical framework, social movement and growing practice around the world. The goal is to not to contest the competitive market economy or promote the solidarity economy, per se, but rather place the social and solidarity economy in relation to industrial ecology (IE). In comparing the SSE to IE in theory and in practice, the chapter discusses how a different economic paradigm might be relevant to the industrial ecology community.

In the section that follows, the social and solidarity economy is defined, with a discussion around the conceptual links between this economic paradigm and industrial ecology; in the second section, three 'solidarity' practices will be discussed in relation to IE, namely: activities in the 'communal' sharing economy, community currencies and 'solidaristic' crowd-funding. By reflecting on the SSE and IE and understanding the opportunities and challenges this presents, the aim of this chapter is to further the work of industrial ecology community, both in research and practice.

\footnotetext{
${ }^{1}$ See Sahakian (2014) for an overview of the WIR as well as community currencies in Argentina and Japan. The WIR bank emerged from the Wirtschaftsring-Genossenschaft cooperative ('Economic Circle' in German, with a play on the word wir, which translates to we or us). Today, more than 60,000 SMEs exchange WIR currency, a unit in parity with the Swiss franc and more commonly circulated in German-speaking Switzerland. Given the small scale of WIR exchanges, there are some doubts as to whether the stabilizing effect can be attributed to the WIR alone; this claim would merit further investigation.
} 


\section{Conceptual Links}

\subsection{What Is the Social and Solidarity Economy?}

The social and solidarity economy finds its roots in the social economy, which emerged in the early period of Western industrialization, in the nineteenth century, when poverty in urban centres was a central concern. The Welsh social reformer Robert Owen founded the cooperative movement at this time, and cooperatives and associations became 'the first line of defence' in rallying to address social ails (Lewis 1997 in Laville 2011). The social economy was relegated to the status of a 'third sector' in the post-war period, when the market economy was seen as responsible for regulating property and currencies, and where the welfare state was considered the primary vector for social action through the redistribution of wealth (Laville 1994). The social economy cast in this role of a 'third sector' represented all other forms of organization, including non-profit and non-governmental activities.

Neoliberal policies, recurring financial crises, as well as the failure of the welfare state to address social issues, all contributed to a rebirth of the social economy in the 1990s. As inequalities widened and environmental issues expanded to a local and global scale, the 'sustainable development' paradigm was brought into question in what has been called a 'crisis of values', leading to a renewed interest in the social economy (Laville and Cattani 2006). Almost 10 years after the first Earth Summit, the participants at the first World Social Forum in 2001 (Porto Alegre, Brazil) rallied around the phrase 'Another world is possible'; the social economy was seen as playing a prominent role in this new world order. For some, the notion of the 'social economy' was insufficient, as this term was too closely associated with the third sector at that time. Arguments were put forward to challenge a definition of the social economy solely based on the type of entity or legal status. ${ }^{2}$ From this effort, the term 'civil and solidarity economy' was coined to account for numerous other initiatives that had emerged, particularly in Europe, that were neither non-for-profit nor non-governmental (Laville 2011). Private enterprises, for example, can be built on social values and have their place in what came to be known as the 'social and solidarity economy' (SSE), primarily in French, Spanish, Italian and Portuguesespeaking countries, in Europe and in the Americas.

As Fraisse (2003) rightly notes, the SSE is being interpreted in different ways around the world. In the United States, members of the SSE aim towards the sys-

\footnotetext{
${ }^{2}$ Historically in France, the definition of the social and solidarity economy had been based on organizational type: all mutual companies and cooperatives fall under this definition. In Western Switzerland, however, another definition is upheld, that of guiding principles and key criteria. A for-profit company can be part of the SSE, as long as it is aligned with the principles of the SSE and profit-making is not the primary goal. The debate about structure versus content of such organizations (Kawano 2009) has been focused on the distinction between theory and practice: some cooperatives may be seeking the economic benefit for their members above all, while some forprofits may be working towards greater social and environmental aims. Simply put, adopting a legal form does not guarantee that an entity becomes part of the social and solidarity economy (Swaton 2011; Defourny et al. 2000).
} 
temic transformation of the economy as a whole, across 'all of the diverse ways that human communities meet their needs and create livelihoods together' (Miller in Kawano et al. 2009: 30), including the private and public sector, and as part of a 'counter-hegemonic political economy' (Satgar 2014) or post-capitalist agenda (Kawano 2013). In other contexts, such as Western Switzerland, the stance is more nuanced: SSE is complementary to the market economy, rather than an alternative; in the Philippines, the strategy is to create supply chains in the social and solidarity economy, mostly in rural areas (Sahakian and Dunand 2015). In some cases, the public sector also takes on the role of promoting the solidarity economy, as is the case in Luxembourg, which has appointed a Ministry of Labour, Employment and the Social and Solidarity Economy. In such cases, there is a risk that the public sector might instrumentalize the social and solidarity economy by outsourcing basic social services to third parties, under the guise of solidarity, an issue that has been hotly debated in SSE circles. As the late Bernard Eme also noted, the instrumentalization can go both ways: civil society actors can also uphold solidarity values in order to access state benefits (Eme (2005) in Laville and Cattani 2006).

As a social movement, the social and solidarity economy (SSE) has grown from local activities to regional and international networks of members, including researchers and practitioners. In the United States, the simpler 'solidarity economy' is the preferred term, which emerged from the U.S. Social Forum in 2007 and resulted in the launch of U.S. Solidarity Economy Network (SEN) (Kawano et al. 2009). In Latin America, SSE has been tied to the new 'development' paradigm termed buen vivir (the good life) (Giovannini 2014) and has been discussed in the literature by several authors (Lemaître and Helmsing 2012; Hillenkamp 2011, 2013; Arruda 2004; Singer 2002; among others). Less is known about SSE initiatives in Asia and Africa. ${ }^{3}$

Conceptually, the SSE is inspired by the notion of reciprocity put forward by Karl Polanyi, who famously argued that the economy is 'embedded' in the social realm; it has a social purpose and is subordinate to and inseparable from social relations (2001, originally published in 1944). Four ideal-type models are put forward in his work: (1) the market economy; and non-market economies including (2) selfsufficiency (including house-holding or relations between family members), (3) redistribution (usually through government) and (4) reciprocity. Several authors have argued for the need for the social and solidarity economy to be multidimensional, to include different types of entities, working progressively towards solidaristic goals, in a more plural economy and across these four ideal types (Laville 2003; Kawano et al. 2009). Fair trade is an example of the SSE in practice, which engages with Polanyi's different ideal types: the products traded are done so in solidarity between consumers and producers, but such activities can benefit from state support (e.g., redistribution), and also engage with the market economy and householding activities, such as craft making in the home.

\footnotetext{
${ }^{3}$ For a recent publication from South Africa, see Satgar (2014); for The Philippines, see Sahakian and Dunand (2015).
} 
The notion of solidarity tends towards a definition of reciprocity as going beyond the duality of giving, receiving and the obligation to give in return, to exchanges across and between different subgroups (Polanyi 1957). Reciprocity in the solidarity economy entails complementary relations based on voluntary interdependence (Servet 2007: 264), or being 'invested with the potential of solidarity, consciously interdependent on others' (Servet 2006: 18). This is an important distinction in theory, as it means that the SSE is not solely about reciprocity in dire straits, out of necessity, towards the relations of 'master and slave', but rather out of an interest in the commons and the community. The work of Elinor Ostrom (2001/1990) is relevant here: collective action can be based on voluntary participation and an identification of needs, going beyond the individual need or that of a self-interested group, to broader social and environmental needs. Sahakian and Servet (in press) propose the term 'communal sharing' to describe forms of sharing that are aligned with the notion of collective action (Sahakian and Servet in press), a theme that will be further explored in the second part of this chapter.

SSE is generally understood as placing human beings at the centre of economic and social life (ISGC 1997). SSE seeks to foster solidarity by placing more importance on people, rather than the accumulation of capital or profit. What inspired early cooperative and associative movements of the nineteenth century and continues to drive efforts in the SSE today are the limitations on profit making: the financial gains for investors are subject to limits (Laville 2011). Another aspect is the emphasis placed on governance systems. The SSE promotes democratic processes within organizations: SSE entities are usually self-managed, self-organized and generally independent from State support. According to Laville (2003), SSE is ultimately about promoting democracy on the local level through economic activity, or the 'democratization' of the economy based on the participatory engagement of all citizens (Defourny and Develtere 1999; Fraisse et al. 2007). The vision is to include all types of people in economic life, engaging them to participate as economic actors, most often at the level of the community. In contexts such as the Global South, the focus is often on rural contexts and on engaging the poor as primary stakeholders in economic activities (Sahakian and Dunand 2015).

To summarize some of the guiding principles that are put forward by SSE actors, the goal of this economy is to place 'service to its members or to the community ahead of profit; autonomous management; a democratic decision-making process; the primacy of people and work over capital in the distribution of revenues' (Defourny et al. 2000). Activities could include some forms of social entrepreneurship; community currencies; micro-credit programs; as well certain worker, consumer and producer cooperatives; community gardens or community supported agriculture; social reinsertion programs; community-run exchange platforms; do-ityourself initiatives; shared services and goods; insurance and financial services, among others. The extent to which these activities fall under SSE umbrella would depend on whether they are progressively seeking to participate in this economy (Swaton and Baranzini 2013), which would need to be evaluated not only in theory and discourse, but also in practice.

In Geneva, Switzerland, companies who want to be part of the SSE must sign a charter, and in doing so, they comply with transparency in reporting, engaging in 
activities that are of collective/public interest, being financially autonomous from subsidies or other forms of support and aiming at non-profit or limited profitmaking. Based on a survey of 195 members in 2008, those employed in the SSE in Geneva experience a low rate of difference between the highest and lowest salary (by a factor of 1.3-2.3), higher average salaries for entry-level work and high rates of people working on flexible schedules (at an average 50-65\% rate of activity) (APRES-GE 2010). In Geneva, members must then commit to progressively put in place, over 2 years, an environmental management policy, participatory forms of management and social management policies that focus on employee diversity and welfare (Swaton and Sahakian 2014). All sectors of the economy are represented among the current 265 members, including health and social services, but also banking and insurance companies, housing cooperatives, food services, arts and leisure, training and education, among others.

Many SSE activities exist as the grassroots level, either marginalized by or hidden within the dominant market economy (Miller in Kawano et al. 2009). SSE tends to include smaller-scale activities, whether local or regional. In some contexts, the ambition is to link together different SSE activities in a supply-chain approach, as is the case in the Philippines where organic feedstock companies and dairy farms are coming together with fair trade associations (Sahakian and Dunand 2015). Examples of larger SSE enterprises and regional efforts are less common, raising questions of scalability. The classic example of a larger scale SSE activity is Mondragón, a cooperative based in the Basque region of Spain that is made up of 258 enterprises organized into a federated governance system including shared financial services and technical support (Kaswan 2014). The cooperatives in Trento county, northern Italy, are also on par with the Mondragón example in terms of scale and effectiveness, according to recent empirical research comparing the two (Prades 2013). The concept of federating cooperative efforts, sharing services and promoting democratic decision-making processes is underway in different contexts, including the Conseil québécois de la co-opération et de la mutualité (CQCM, Canada) and the Democracy Collaborative centred around the Evergreen Cooperatives in Cleveland, Ohio (ibid.). A magic number is usually upheld as representing the percentage of jobs that are involved in the social and solidarity economy: for both France and the City of Geneva, the SSE is said to represent approximately $10 \%$ of salaried employment (INSEE 2012; Dunand 2012).

\subsection{What Are the Conceptual Links between SSE and IE, and the Limits?}

In the industrial ecology field, economic profit is not a central preoccupation. The payback of certain efforts in terms of return on investment is important in practice, where industrial ecology projects are concerned, but profit generating is not explicitly part of industrial ecology conceptual developments. The founding theoretical principles in IE draw from bio-economics, notably the link between natural laws 
and principles, such as thermodynamics and economic systems (Georgescu-Roegen 1971, 2006). In this perspective, economic activities draw from and are dependent on ecosystem services, suggesting that there are limits to economic growth (Daly 1977; Jackson 2009). Understanding patterns and trends from a biophysical perspective means assessing values based on environmental resources (material and energy), rather than solely price valuation.

IE and SSE therefore share the principle that economic activity should be subordinated to other factors. Yet industrial ecology privileges the biophysical dimension whereas the social and solidarity economy privileges the social dimension. These different priority areas could be problematic: Is it more important to aim for solidarity in social relations and governance structures, or to minimize energy and material throughputs? Can one be done at the expense of the other? This raises ethical issues in industrial ecology: What if optimal symbiosis is achieved in companies that exploit labour, for example? This also raises environmental sustainability issues among SSE enterprises: Can social goals be achieved to the detriment of environmental considerations?

Beyond the conceptual underpinnings that relate industrial ecology to bioeconomics and ecological economics, the novelty of industrial ecology is to draw inspiration from natural systems. According to Erkman, 'the entire industrial system relies on resources and services provided by the biosphere, from which it cannot be dissociated' (1997: 1), yet material and energy throughputs could be better managed through a more holistic approach to organizing economic activities and industrial systems. Biomimicry in industrial ecology implies tending towards reduced resource throughputs and negative impacts. As a descriptive and analytical method, industrial ecology helps to uncover the 'metabolism' of systems, drawing from a comparison with living organisms (Ayres and Simonis 1994) towards understanding 'anthropogenic complex and coupled systems' (Fischer-Kowalski et al. 2009). In addition to describing and analysing, IE suggests how such a system might be 'restructured to make it compatible with the way natural ecosystems function' (Erkman 1997: 1) and is therefore also an operational tool.

Ehrenfeld (2000) goes a step further in distinguishing these practical features in the field of IE from its founding conceptual basis, which tends towards a normative context and can in turn shape paradigmatic thinking. Understood in analogy to natural systems, industrial ecology is a practical tool; in using natural systems as a metaphor, industrial ecology has the potential to go beyond prescription and techno-focused solutions to become transformative (Ehrenfeld 2003; Hess 2009). The analogy with natural systems allows IE to disengage with questions related to people and power relations. There have been efforts to embed industrial ecology in social relations (Boons and Howard-Grenville 2009). Some work has been done relating IE to fair employment (Alsamawi et al. 2014), legal considerations (Slone in Cohen-Rosenthal and Musnikow 2003) and the role of consumer culture and ethics (Hertwich 2005b; Ehrenfeld 2008; Sahakian and Steinberger 2011), but these aspects have not been sufficiently theorized to date. The work of the late E. CohenRosenthal on environmental, labour and social issues is a key contribution in this area. His focus on workplace issues (Cohen-Rosenthal 1979), specifically in the 
industrial ecology community (Cohen-Rosenthal 2004), was consistently critical of reductionist strategies that would rely solely on engineering know-how, proper technologies and market-based incentives. For Cohen-Rosenthal, the focus should be on social processes, or the actual points of connection between material and energy flows, and specifically connections between people. Yet little attention is given in IE to the relation between interests, institutions and resources (Opoku 2004), and this dimension remains to be further conceptualized - although interest in this dimension has been growing in the past decade, as we will now turn to.

IE engages with various tools, which are now considered a part industrial ecology approaches, including Input-Output Accounting and Material Flow Analysis, as well as Life Cycle Assessments. The value of LCA has been to extend beyond the 'end of pipe' perspective, which only addresses final outputs, in terms of pollution and environmental degradation. Rather, inputs and outputs are described and can be quantified and qualified across the production-consumption chain, from extraction of natural resources, through manufacturing, distribution, usage and final disposal. In more recent years, social LCA has developed to consider the social impacts in the life cycle of products and processes (UNEP 2009; Andrews et al. 2009; Hauschild et al. 2008), with more recent work in developing a social hotspots database that includes a consideration of labour intensity and worker rights (Benoit-Norris et al. 2012) and on integrating occupational health and safety standards (Scanlon et al. 2015). One aspect of the social and solidarity economy is that the primacy of people over profit is not an 'end of pipe' gesture, but rather embedded across the economic activity in question, from its guiding principles and mission, to how salaries and employee benefits are organized, to how profit is shared. We will come back to this notion in the next section of this chapter, when we consider forms of 'end of pipe sharing' to distinguish more robust solidarity economy activities from 'business as usual'.

The notion of reciprocity, which is an important concept underpinning the SSE, is interesting to explore in relation to IE. If we continue with the notion of IE as being based on a metaphor, can we identify any forms of reciprocity in nature? In other terms, do we see cooperation or competition in natural systems? Ehrenfeld (2000) suggests that a balance is needed between both. Does altruism exist in nature? Perhaps something closer would be mutualism, which would suggest cooperation between members that lead to mutually beneficial or even neutral outcomes. For Ehrenfeld, '...the power of the concept of industrial ecology lies in its normative context and in its potential to shape paradigmatic thinking. It is normative in the sense that (...) three features of the ecological metaphor - community, connectedness, and cooperation are characteristics we should strive for in designing our worlds.' (Ehrenfeld 2000: 238). These three features, of community, connectedness and cooperation, are closely related to the social and solidarity economy and would merit being further conceptualized. We could draw on the work of Pierre-Joseph Proudhon (1809-1865) here, the father of mutualism in economic theory, who suggested that human activities could be mutualized towards the creation of a collective good.

In terms of governance systems, the notion of voluntary engagement in complementary relations, which is important in the SSE literature, is not explicit in the IE literature. Forms of auto-organization are usually upheld as the preferred way of 
achieving symbiosis, defined as system exchanges that convert "negative environmental externalities in the form of waste that used to be discarded into positive environmental externalities such as the spillover benefits of decreased pollution and reduced need for raw material imports' (Chertow and Ehrenfeld 2012: 15). Industrial symbiosis research points to the relevance of self-organizing systems, working in mutually beneficial forms of cooperation, with mobilization capacity, and on a local and regional scale (Massard et al. 2014; Chertow and Ehrenfeld 2012; Boons and Spekkink 2012; Chertow 2007), which is very much the terrain of the social and solidarity economy. As different cooperative movements begin to federate and create new models in the SSE, the industrial ecology community could gain from understanding how services are shared and maximized between these entities. Cooperatives are not the usual stomping ground of industrial ecology activities, but could represent an interesting starting point for discussions that bring together social and biophysical dimensions.

Given the important role of small-to-medium enterprises (SMEs) in developing countries and following the fourth World Social Forum in 2004 (Mumbai, India), a report focusing on the social responsibility of SMEs also sought to make a link between industrial ecology and the solidarity economy. In that report, the late Ramesh Ramaswamy - co-author of a novel book on applied industrial ecology in developing countries and particularly India (Erkman and Ramaswamy 2003) - suggested that SMEs could gain competitive advantages in the global market by organizing production into 'complementary clusters' particularly in the agricultural sector (Asian Coalition 2004: 17). The report suggested industrial ecology could enhance the 'social responsibility' of SMEs in four ways, by addressing: 'producers (greater consciousness in using biodegradable and recyclable materials, lesser waste, more profits); consumers (better quality products); the environment (lesser toxic wastes); and society at large (more socially responsible enterprises, healthier environment)' (ibid.).

In theory, industrial ecology principles should be retained, no matter the organizational structure or system at hand, be it a for-profit SME or a cooperative. Here industrial ecology joins recent interpretations of the social and solidarity economy, in focusing more on how guiding principles can be applied in practice, rather than on institutional settings. That being said, there tends to be a bias towards democratic systems in the industrial ecology literature; the same is true for the social and solidarity economy, which upholds democracy as the key governance system. On this level, the two fields are compatible.

\section{Linkages Between the SSE and IE in Practice}

\subsection{The Sharing Economy vs. End of Pipe Giving: Applicability to IE}

The sharing economy is generally understood as involving 'sharing' in the creation, financing, production, distribution and consumption of a variety of goods and services. Certain activities that fall under this banner are part of the current dominant 
market economy, based on the maximization of utility and the meeting of needs towards pecuniary goals. On the other hand, the sharing economy could be seen as part of the solidarity economy, including activities that aim towards solidarity and mutual support. In the latter reading, 'sharing' would be less about maximizing unused resources and more about placing resources 'in the commons', drawing from theories in environmental governance and alluding to forms of voluntary, collective action around resource usage (Ostrom 2001/1990). A key distinction here is to understand sharing not as the distribution of pieces of a pie, albeit in collaborative ways, but rather 'sharing' based on an understanding of identified and recognized societal needs, through democratic processes, and with regards for current and future generations (Servet 2014) - or as part of the social and solidarity economy.

In either definition of sharing - as part of the competitive market economy or the solidarity economy - the notion of optimizing resources is highly compatible with industrial ecology principles. The de-materialization of the economy has been a central theme in industrial ecology these past years. Placing value on under- or unused resources is also promoted in the 'sharing' economy. Industrial ecology approaches could help consider the wider system, beyond a unit or transaction, to determine whether there are any rebound effects associated with such forms of sharing. By renting fashionable clothing, for example, does overall private acquisition of consumption increase or decrease? Has car sharing led to increases in private car ownership or increases in public transportation, and over what scale? In terms of describing activities within the sharing economy, industrial ecology could help provide a lens through which to understand where 'sharing' is actually taking place: is there only 'end of pipe sharing', once a resource has already been developed and privately owned; or is 'sharing' built into the entire process, in how a product or service is conceived, delivered and maintained? As an operational tool, industrial ecology could help suggest how certain practices within a sharing economy could be restructured, towards a normative goal of more efficient resource usage and lessened environmental impact. Industrial ecology has a role to play in helping to better define whether the sharing economy is leading to a more optimal system overall and to what extent, based on biophysical considerations.

The sharing economy, in all different forms, is well underway and provides an opportunity for industrial ecology practitioners to break with the notion of 'production and consumption' to consider new ways of maximizing resources, from peerto-peer exchanges, as well as new business models. The 'sharing' taking place in the social and solidarity economy could therefore be a rich terrain for further study and practice. Industrial ecology methodologies could be applied for better evaluating and guiding activities towards more efficient 'resource' sharing; but perhaps more importantly, advances in sharing in the social and solidarity economy could further inform the industrial ecology community towards a more holistic reading of socioindustrial ecosystems - integrating questions of current and inter-generational solidarity and mutual support, as well as questions related to power, trust, wellbeing and governance, towards collaborative industrial eco-systems.

The emphasis on maximizing local resources towards symbiosis could benefit from some of the approaches being developed in the sharing economy, not least the use of information and communication technologies that distinguish from more tra- 
ditional forms of sharing. Tools for 'sharing' are being developed through new smart phone apps and web sites, using participative methods in their design and deployment, and based on establishing relations of trust through peer review systems. Trust has been a central theme in symbiosis studies, within the industrial ecology community, and much could be learned from the 'sharing' economy in this respect. One aspect of the sharing economy that is currently gaining the attention of researchers and practitioners working on labour relations is the question of casualized labour or the precarity of labour in the sharing economy. In considering the future of environmental reporting, attention should also be placed on labour issues as well as human rights (Fatkin in Sarkis 2001). The work of Cohen-Rosenthal would be relevant here, to place a focus once more on labour conditions and the workplace, as a way to contribute to employee and societal wellbeing - as discussed in the Chap. 8 by Wiedmann in this volume.

Finally, the maximization of resources through 'sharing' could be more effective in some cases when taken out of the market economy and placed into the solidarity economy. As Guillaume Massard suggests, founder of SOFIES industrial ecology consulting group, 'the solidarity economy in Geneva allows the development of business models for material reuse with other conditions than the typical market conditions, making it attractive to recycle certain materials that would not be collected if subjected to the market economy prices' (Massard 2015). In Geneva, social reinsertion programs are part of the SSE, whereby unemployed people are given positions in enterprises as part of their training, some of which focus on recycling materials such as electronic products. In the case where the State does not offer subsidies to an enterprise directly but allows for this form of subsidized labour, the business model for recycling such products can become more attractive. 'Everything that goes beyond market profitability, this is where the solidarity economy can introduce different biases, such as complementary currencies or subsidized labour,' according to Massard.

\subsection{Community Currencies: Idea of Démurage and Applicability to IE}

National currencies are a fairly recent invention: centralizing money was first conceived by European royalty, in attempts to limit feudal power, then reinforced by empires seeking tighter control of the colonies, and finally by the modern nationstates. Money is far from being neutral: it affects the kind of transactions we make, and the kinds of relations we establish with those exchanges and within society (Lietaer and Kennedy 2008); the value of money is ultimately a social construct (Graeber 2001). Historically, diverse monetary systems always existed in parallel, around the world, from Europe to Indonesia (Sahakian 2014). The thirteenth century Republic of Venice had two types of currencies for external commerce, the ducat (silver) and zecchino (gold), and two other currencies in less precious metals 
for local exchanges, the nasoni and cavalotti (Lietaer and Kennedy 2008). In making a parallel to industrial ecology concepts, having different types of currencies working together in a complementary manner tends towards ecosystem diversity. Our national and supra-national currencies, by contrast, are similar to monoculture farming; a weak euro impacts the entire euro-zone along with international trade, with no other currencies in place to provide a stabilizing effect. The argument for complementary currencies rests on the need for system diversity in our monetary systems.

Beyond national currencies, other forms of monetary units exist and are widely exchanged as complementary currencies, such as airline mileage (The Economist 2005) and Bitcoins (McMillan 2014). One definition of complementary currencies is that they exist at the nexus of unsatisfied needs and under-utilized resources (Lietaer and Kennedy 2008). In 2010, an estimated one million people worldwide engaged in complementary currency systems in over 4,000 associations in over forty countries (Blanc 2010); no doubt this number has increased since then. Currencies can have aims other than facilitating exchange, creating wealth, promoting brand loyalty or allowing for the redistribution of wealth through taxation. This is where the notion of community currencies comes in, as a subset of complementary currencies, and tied to the guiding principles of the social and solidarity economy (SSE). Community currencies are often designed towards social or environmental aims, are generated in and spent in a given region and not tied to national currencies, thus sheltered from the whims of international financial markets. The advocates of community currencies point to the need to diversify the local economic system and harness the potential of regional wealth creation and related expenditures. For Blanc (2010), one of the main objectives of such currencies is to 'resist globalization' and encourage the use of local income for local production and consumption; a second objective is to benefit local populations through a fairer distribution of wealth, rather than wealth accumulation among an elite; third, such currencies should aim at transforming the nature of trade and solidifying social relations based on trust, proximity between producer and consumer and the notion of producer as consumer (or 'prosumer'). Handbooks designed to guide those interested in stimulating regional economies are available (Lietaer and Kennedy 2008).

Examples of community currencies have flourished in the past two decades and around the world through what are called Systèmes d'échanges locaux (SEL) or Local Exchange Trading Systems (LETS). The first LETS in the UK was created in Norwich in 1985, growing by 2001 to include 300 trading schemes, involving 22,000 people and an annual turnover equivalent of $£ 1.4$ million (Williams et al. 2001 in Seyfang 2007). The local exchange systems can involve the trading of different products and services, but also time as a resource. This relates to time banking, a form of exchange based on the egalitarian notion that each member's time is equivalent to another's. Services such as baby-sitting or painting can be exchanged for computer programming or legal advice, with no distinction between the type of service offered; it is an hour of time that is being exchanged. Time banks are increasingly the subject of academic research: in the recent edited volume, Sustainable lifestyle and the quest for plenitude (Schor and Thompson 2014), the up- and down- 
sides of a Boston time bank are discussed, based on empirical research. The reason LETS have remained small and marginal, in relation to the dominant market economy, may have to do with a number of factors, which might include the question of quality of skills being traded, the availability of staple goods and services and government regulations that count LETS earnings as equivalent to cash income, among others (Seyfang 2007).

Japan was a forerunner in community currency experiments: in the 1970s, a volunteer labour bank allowed for inter-generational care, but was modestly successful (Hirota 2011). In the late 1990s, the Director of Service Industries Division of the Ministry of Economics, Trade and Industry (METI), Toshiharu Kato, founded the Eco-Money network to support regional experiments in new currencies across Japan. ${ }^{4}$ By 2003, 25 projects were implemented by 55 different organizations across the country. The main roles of Eco Money projects are to enhance community integrity, foster public participation, create a sustainable economic environment and maintain a viable natural environment (Okuno 2004). In the Chiba prefecture, the "peanut" was introduced as a regional currency, where one "peanut" is equal in value to one yen; one hour of work is equal in value to 1,000 peanuts, with all transactions recorded as "plus and minuses" on individual record sheets. For example, peanuts can be gained by helping someone build a web site and driving a neighbour to the hospital, which can then be used towards paying for a language class (Okuno 2004). Visitors to the 2005 World Exposition in Aichi, Japan, could earn Expo EcoMoney points through pro-environmental actions (e.g., bringing your own bag to the store, for example), which were then exchanged for services or products or used to make donations to environmental projects. In another example in the Yasu-Cho community in Shiga prefecture, community members came together to help protect local forests and raise environmental awareness. An eco-yama (eco-mountain) card was issued to encourage people to earn credit by helping to maintain the forest or to help develop local renewable energies (solar and biomass). Local stores and businesses agreed to accept these credits, creating a local currency in solidarity between local commerce, residents and the natural environment.

Levine (2003) suggests that one of the limits of the IE-natural system analogy is that products play a central role in the economy: interactions or exchanges in industrial ecology are mutualistic when they create a positive feedback loop in terms of product value and related economic benefits, yet there is no 'analogy' with a socially constructed 'product value' in natural systems. We might imagine new ways of assigning value to under-utilized material and energy resources, by creating new ways of trading such products and services outside of the capitalist market economy - by incorporating social and environmental values, for example. In relation to

\footnotetext{
${ }^{4}$ According to Lietaer (2004), eco-monies were introduced as part of a regional development strategy following Kato's investigations in regional development elsewhere. His study of high-tech development models in the United States, including Silicon Valley, lead him to conclude that regional learning clusters should be promoted, involving entrepreneurs and small corporations, alongside ecological, economic, and community-driven initiatives (Okuno 2004). Complementary currencies were seen as part of this design.
} 
climate change, one proposal is to reward low-carbon investments through the creation of a monetary unit based on the social cost of carbon (SCC): in this example, 'the SCC is neither a market price, nor the tax incorporated in the prices of goods. It is a notional price defined as the social value of avoided $\mathrm{CO}_{2}$ emissions' (Aglietta et al. 2015: 4), which relies on a strong independent body to calculate exactly what that price might be. In this approach, the monetary unit is assigned a politically negotiated value, and not a value based on the whims of a capitalist marketplace. ${ }^{5}$

To further this example around a SCC currency, the notion of démurage could be of interest, defined as a negative incentive against the accumulation of notes. ${ }^{6}$ Démurage is a familiar term in complementary currencies, as it stimulates the constant exchange of complementary currencies, against the accumulation of wealth and towards its distribution. When a currency has been assigned démurage, the more money you accumulate over time, the lesser the value of that money. In the example of a monetary unit based on the social cost of carbon, this could incentivise the holders of this currency to accelerate their investments in low-carbon projects rather than hoard carbon credits for the purpose of financial speculation. To return to the founding metaphor of IE, the accumulation of benefits (i.e., endless profits) is not apparent in ecosystems, which tend towards equilibrium. Démurage could limit the effects of accumulation for a complementary currency that strives towards environmental goals. Whether this type of system would be state and independently regulated (as Aglietta et al. suggest in relation to this version of a monetary unit based on the SCC), driven by enterprises, or managed by everyday people remains to be debated, along with an assessment of the resulting environmental impacts.

\subsection{Crowdfunding in the Solidarity Economy: towards IE Principles}

Rifkin claims in his latest book (2014) that we are facing a transformation in modes of production and operation, largely due to new technologies, and in a transition from a capitalist to collaborative marketplace. The financial sector is no exception to this trend: promoted through the Internet and mobile payment services, new

\footnotetext{
${ }^{5}$ There is much debate around the social cost of carbon (SCC), as well as the notion of a more versatile shadow price of carbon (SPC) used internally by companies in their strategic planning (CDP 2013) or in the policy arena (Price et al. 2007). The point here is not to discuss these developments in depth but rather illustrate the example of how a monetary unit could operate outside of the marketplace, based on values assigned through policy negotiations - assuming democratic processes and a strong independent regulatory body.

${ }^{6}$ The notion of démurage emerged in 1933, when the Austrian village of Wörgl introduced a new currency designed with a negative incentive against the accumulation of the notes. The National Bank of Austria closed down this experiment within a few months, fearing it would be replicated to other regions and ultimately challenge the national currency (Sahakian 2014). The concept is still alive today, however, with various community currencies building in démurage to insure the circulation of notes.
} 
opportunities for raising donations, credit and loans abound. Given the credit crunch in certain contexts, some of these online platforms offer more favourable interest rates than traditional lending mechanisms. Certain financial platforms are "business as usual', facilitated by new technologies; however, some of these online services could fall under the umbrella of the social and solidarity economy. In Sahakian and Servet (in press), the distinction is made between crowdfunding that aims towards 'communal sharing' versus self-interest. Related to the former definition, crowdfunding that tends towards solidarity implicates people coming together to address a broader need, serving either social or environmental aims.

Certain crowdfunding platforms attempt to achieve these aims (e.g., SPEAR and Kisskissbankbank), while others focus specifically on promote investments in renewable energies (e.g., Solar Mosaic and Wiseed). ${ }^{7}$ Certain platforms propose both 'business as usual' projects as well as projects that aim at a social good. Take for example Kickstarter: raising funds for the customizable smart watch 'Pebble" ${ }^{8}$ does not aim towards achieving a greater environmental or social common good (although this may be a matter of perspective), whereas raising funds for favela painting does aim to transform an under-privileged area of Rio. In the case of Smart Angels or Unilend, ${ }^{9}$ the projects financed tend to fall in the 'business as usual' category and these platforms are also based on capitalistic notions, in that they are privately owned and seek pecuniary gains. The type of institutional framework governing a platform does not determine its mission of purpose. There is currently very little information publicly available on how such platforms operate in practice, including their governance systems, and this merits further study, particularly in relation to notions of democratic governance systems.

Assessing the level of 'communal sharing' and 'solidarity' that takes place through crowd-funding entails considering a range of factors, including the motivations for setting up such a platform, for proposing projects and contributing funds. Such projects would need to be evaluated over time, to ensure that they deliver on their promises. Crowdfunding could benefit the industrial ecology community in one obvious way, in raising funds for interesting and novel projects. In other sectors, crowdfunding has been used to test the viability or public support for certain initiative. Crowdfunding for a new biogas facility for example could demonstrate the interest and acceptance among the general public for such a project.

There is yet another way in which crowdfunding could work in synergy with industrial ecology: as an investment tool. The economic gains made through reducing consumption and via efficiency measures can lead to decreases in consumption that are lower than expected through a direct rebound effect (Hertwich 2005a). More challenging to measure is 'indirect rebound', where for example money saved through reduced energy or material consumption in one consumption area (e.g.

\footnotetext{
${ }^{7}$ See associated websites: www.spear.fr, www.kisskissbankbank.com, joinmosaic.com, www. wiseed.com

${ }^{8}$ See Pebble project page on the Kickstarter website: www.kickstarter.com/projects/597507018/ pebble-e-paper-watch-for-iphone-and-android (Retrieved March 3, 2015).

${ }^{9}$ See: www.smartangels.fr, www.unilend.fr
} 
switching from car journey to bicycles) leads to funds spent on other energy- and material-intensive activities (e.g., a long distance flight). Economy-wide rebound considers the effects such rebounds might have across the economy (Druckman et al. 2011). Using the savings generated from increased efficiencies to invest in projects that aim towards industrial ecology goals could be one way to counter such rebounds (as also discussed by Druckman and Jackson, Chap. 9 in this volume), with certain crowdfunding platforms providing the opportunity for such investments (Sahakian and Servet in press). While quantifying and qualifying rebounds is a difficult exercise, allowing more opportunities for people to invest more directly in environmentally sound and socially just activities, seems like a logical way forward.

\section{Conclusion}

In this chapter we have considered the links and tensions between the fields of the social and solidarity economy (SSE) and industrial ecology (IE), highlighting new directions for reflection, research and practice in industrial ecology. This exercise raises more questions than answers. The first main conclusion is about value systems and paradigms: the SSE tends to place people over profit; the IE field tends to put planet over profit, both therefore go beyond pecuniary interests yet are based on differing normative goals. By placing these two fields side by side, it becomes apparent that the IE field could further theorize questions related to social context and power structures. The notion of solidarity in relation to the workplace is becoming increasingly topical in discussions around the sharing economy: ethical issues are emerging around questions of employment security, health and safety standards, employee personal development and employee sharing in value creation and related wealth (Conway 2014). The question of labour precarity will no doubt increase in the coming years, thus the relevance of Cohen-Rosenthal's contribution to the IE literature as well as more recent work on employee wages, health and safety. In addition to the increasing focus on consumption and consumers in the IE field over the past decade, more attention could also be given to production and specifically labour relations: would a 'world of work' based on solidarity contribute to greater prosperity?

Beyond considering how IE might integrate principles from the SSE, another approach would be to question whether solidarity, in a community or between different stakeholders in an economic activity, might be a promising foundation for industrial symbiosis (see Chaps. 5 by Chertow and Park, and 19 by Bailey in this volume). Rather than 'create' an eco-community or industrial eco-park through topdown policies, or hope that bottom-up forms of symbiosis will emerge from selforganizing entities, one interesting new avenue for the industrial ecology community would be to assess where the SSE is already active in certain fields - at the level of cooperatives, SMEs, larger enterprises, neighbourhoods or regions - then build on the existing relations of trust and solidarity, to maximize resource efficiency. 
Whether 'solidaristic' enterprises would be more receptive to such efforts and more adept at embracing such resource exchanges remains to be seen and would be an interesting area of future research. Another field of inquiry would be to ascertain to what extent companies already involved in symbiotic relations also embody social and solidarity values. Chertow and Ehrenfeld found that 'one of the most distinctive elements of industrial symbiosis is that, while all industrial actors seek to reduce private costs and increase private benefits, those in the symbiotic networks that have been studied also participate in the creation of public environmental benefits' (2012: 18). Here, the SSE can contribute through an analysis of the profit structure, governance system, societal aims and, more generally, in better understanding the culture and values within such systems. Two other fields of inquiry involve the consideration of 'solidaristic' crowdfunding as an opportunity for abating economy-wide rebound effects through the promotion of more socially just and environmentally sound investments; and finally, the potential for complementary currencies to work towards industrial ecology aims, such as reducing global carbon emissions.

One of the weaknesses of the social and solidarity economy has been that of scale: although various institutions exist at the level of cities, countries and regions to federate activities across sectors, the actors within the SSE typically operate on a more micro scale. Over the past few years, there has been increasing attention to macroeconomic thinking in the industrial ecology and ecological economics community, questioning notions of wellbeing and prosperity, the inadequateness of current models and the need for transformative investments in the future (Røpke in Cohen et al. 2013; Jackson 2009; Victor 2008). As Tim Jackson put it 'The truth is that there is as yet no credible, socially just, ecologically sustainable scenario of continually growing incomes for a world of 9 billion people.' (2009: 86). The social and solidarity economy is not a magic wand solution and operates at the margins of the dominant capitalist economy, yet it is well underway and expanding, in research and practice. Reflecting on how the SSE and industrial ecology community might come together towards more macro-level perspectives would be a worthy exercise. One main outcome of this analysis is that transactions and exchanges are important flows, but more attention should be placed on the underlying values holding together our everyday practices and put forward in our economy, workplaces and society as a whole - including social and environmental values that are not always aligned.

Acknowledgements The author would like to thank the editors for shepherding this chapter into this volume and for their comments. I am indebted to the Industrial Ecology Group at the University of Lausanne for their generous contribution of ideas, including Suren Erkman, Loïc Leray, Frederic Meylan, Ignes Contreiras, Theodore Besson and Vincent Moreau. I thank particularly Jean-Michel Servet for his detailed comments in relation to the solidarity economy. I thank Guillaume Massard for his insights, as well as Maurie Cohen and Sophie Swaton for fruitful exchanges around sharing. The term 'end-of-pipe' sharing emerged from a lively discussion with Nedal Nassar at the 2014 GRC on Industrial Ecology.

Open Access This chapter is distributed under the terms of the Creative Commons Attribution Noncommercial License, which permits any noncommercial use, distribution, and reproduction in any medium, provided the original author(s) and source are credited. 


\section{References}

Aglietta, M., Espagne, E., \& Fabert, B. P. (2015). A proposal to finance low carbon investment in Europe. Finance Stratégie, 24, 1-7.

Alsamawi, A., Murray, J., \& Lenzen, M. (2014). The employment footprints of nations. Journal of Industrial Ecology, 18(1), 59-70.

Andrews, E. S., Barthel, L.-P., Tabea, B., Benoît, C., Ciroth, A., Cucuzzella, C., Gensch, C.-O., Hébert, J., Lesage, P., Manhart, A., \& Mazeau, P. (2009). Guidelines for social life cycle assessment of products. C. Benoît. Paris: UNEP/SETAC Life Cycle Initiative.

APRES-GE. (2010). Etude statistique: Photographie de l'économie sociale et solidaire à Genève. Geneva: Chambre de l'Economie Sociale et Solidaire.

Arruda, M. (2004). Humanizar o Infra-Humano. A formação do ser humano integral: Homo evolutivo, práxis e economia solidária. Petropolis: Vozes/Pacs.

Ayres, R., \& Simonis, U. E. (1994). Industrial metabolism: Restructuring for sustainable development. Tokyo: United Nations University Press.

Benoit-Norris, C., Cavan, D. A., \& Norris, G. (2012). Identifying social impacts in product supply chains: Overview and application of the social hotspot database. Sustainability, 4, 1946-1965.

Blanc, J. (2010). Community and complementary currencies. The human economy: A citizen's guide (pp. 303-312). Cambridge/Malden: Polity Press.

Boons, F., \& Howard-Grenville, J. (Eds.). (2009). The social embededness of industrial ecology. Cheltenham/Northampton: Edward Elgar.

Boons, F., \& Spekkink, W. (2012). Levels of institutional capacity and actor expectations about industrial symbiosis: Evidence from the Dutch stimulation program 1999-2004. Journal of Industrial Ecology, 16(1), 61-69.

Botsman, R., \& Rogers, R. (2010). What's mine is yours: The rise of collaborative consumption. New York: HarperCollins Publishers.

CDP. (2013). Use of internal carbon price by companies as incentive and strategic planning tool: A review of findings from CDP 2013 disclosure. New York: CDP Worldwide.

Chertow, M. R. (2007). "Uncovering" industrial symbiosis. Journal of Industrial Ecology, 11(1), $11-30$.

Chertow, M., \& Ehrenfeld, J. (2012). Organizing self-organizing systems. Journal of Industrial Ecology, 16(1), 13-27.

Coalition, A. (2004). Report on the seminar on social responsibility of SMEs for development of people's economy. Asian coalition for SME development. Mumbai: World Social Forum.

Cohen, M. J. (2014). Some reflections on the sharing economy: Where is the sharing in car "Sharing”? Retrieved February 2, 2015, from http://ssppjournal.blogspot.ch/2014/02/somereflections-on-sharing-economy.html

Cohen, M. J., Brown, H. S., \& Vergragt, P. J. (Eds.). (2013). Innovations in sustainable consumption: New economics, socio-technical transitions and social practices. Advances in ecological economics. Cheltenham/Northampton: Edward Elgar.

Cohen-Rosenthal, E. (1979). Enriching workers' lives. Change, 11(5 - Education and Work: Two Worlds or One?), 64-66.

Cohen-Rosenthal, E. (2004). Making sense out of industrial ecology: A framework for analysis and action. Journal of Cleaner Production, 12, 1111-1123.

Cohen-Rosenthal, E., \& Musnikow, J. (Eds.). (2003). Eco-industrial strategies: Unleashing synergy between economic development and the environment. Sheffield: Greenleaf publishing.

Conway, M. (2014). The downside to lower labor costs in the sharing economy. Huff Post Business. Retrieved March 3, 2015, from http://www.huffingtonpost.com/maureen-conway/thedownside-to-lower-labor-costs_b_5759122.html

Daly, H. E. (1977). Steady-state economics: The economics of biophysical equilibrium and moral growth. San Francisco: W.H. Freeman and Company.

Defourny, J., \& Develtere, P. (1999). Origines et contours de l'économie sociale au nord et au sud. L'économie sociale au Nord et au Sud (pp. 25-50). Brussels: De Boeck Université. 
Defourny, J., Develtere, P., \& Fonteneau, B. (Eds.). (2000). Social economy North and South. Leuven and Liège, HIVA and Centred' Economie Sociale.

Druckman, A., Chitnis, M., Sorrell, S., \& Jackson, T. (2011). Missing carbon reductions? Exploring rebound and backfire effects in UK households. Energy Policy, 39, 3572-3581.

Dunand, C. (2012). L'économie sociale et solidaire: une troisième voie. Retrieved February 2 , 2015, from http://www.apres-ge.ch/node/32911

Ehrenfeld, J. R. (2000). Industrial ecology: Paradigm shift or normal science? American Behavioral Scientist, 44(2), 229-244.

Ehrenfeld, J. (2003). Editorial: Putting a spotlight on metaphors and analogies in industrial ecology. Journal of Industrial Ecology, 7(1), 1-4.

Ehrenfeld, J. R. (2008). Sustainability by design: A subversive strategy for transforming Our consumer culture. New Haven/London: Yale University Press.

Ellen MacArthur Foundation. (2013). Towards the circular economy: Economic and business rationale for an accelerated transition. Retrieved February 3, 2015, from http://www.ellenmacarthurfoundation.org/circular-economy/circular-economy/towards-the-circular-economy

Erkman, S. (1997). Industrial ecology: An historical view. Journal of Cleaner Production, 5(1-2), $1-10$.

Erkman, S., \& Ramaswamy, R. (2003). Applied industrial ecology: A new platform for planning sustainable societies: Focus on developing countries with case studies from India. Bangalore: Aicra Publishers.

Fischer-Kowalski, M., Hertwich, E., \& Lifset, R. (2009). Strategies and tools for refashioning the social metabolism: IE as a key to the transition to sustainability. ISIE conference, Lisbon, Portugal.

Fraisse, L. (2003). Quels projets politiques pour l'économie solidaire? Cultures en mouvement, 62, 4.

Fraisse, L., Guérin, I., \& Laville, J.-L. (2007). Economie solidaire: des initiatives locales à l'action publique. Introduction. Revue Tiers Monde, 190, 245-253.

Gansky, L. (2010). The mesh: Why the future of business is sharing. London: Portfolio Penguin.

Georgescu-Roegen, N. (1971). The entropy law and the economic process. Cambridge, MA: Harvard University Press.

Georgescu-Roegen, N. (2006). La Décroissance: Entropie, Ecologie, Economie (1979). Paris: Sang de la Terre.

Gibson-Graham, J. K. (2006). A postcapitalist politics. Minneapolis: University of Minnesota Press.

Gibson-Graham, J. K. (2008). Diverse economies: Performative practices for 'other worlds'. Progress in Human Geography, 32(5), 613-632.

Giovannini, M. (2014). Indigenous community enterprises in Chiapas: a vehicle for buen vivir? Community Development Journal, Advance access online March 3. doi:10.1093/cdj/bsu019.

Graeber, D. (2001). Toward an anthropological theory of value: The false coin of our own dreams. New York: Palgrave.

Hart, K., Laville, J.-L., \& Cattani, A. D. (Eds.). (2010). The human economy: A citizen's guide. Cambridge/Malden: Polity Press.

Hauschild, M. Z., Dreyer, L. C., \& Jørgensen, A. (2008). Assessing social impacts in a life cycle perspective-Lessons learned. CIRP Annals - Manufacturing Technology, 57, 21-24.

Hertwich, E. G. (2005a). Consumption and the rebound effect: An industrial ecology perspective. Journal of Industrial Ecology, 9(1-2), 85-98.

Hertwich, E. G. (2005b). Editorial: Consumption and industrial ecology. Journal of Industrial Ecology, 9(1-2), 1-6.

Hess, G. (2009). Forum: L'écosystème industriel. Difficulté épistémologique d'une telle analogie. Natures Sciences Sociétés, 17, 40-48.

Hillenkamp, I. (2011). Solidarités, marché et démocratie: éclairages boliviens. Finance \& The Common Good/Bien commun II-III(37-38), 76-95. 
Hillenkamp, I. (2013). L'économie solidaire en Bolivie: entre marché et démocratie. Geneva: Editions Karthala.

Hirota, Y. (2011). What have complementary currencies in Japan really achieved? Revealing the hidden intentions of different initiatives. International Journal of Community Currency Research, 15(D), 22-26.

INSEE. (2012). L'économie sociale en 2012. Retrieved February 2, 2015, from http://www.insee. $\mathrm{fr} / \mathrm{fr} /$ themes/detail.asp?reg_id=99\&ref_id=eco-sociale

ISGC (1997). Lima Declaration. International Solidarity Globalization Conference, Lima, Peru.

Jackson, T. (2009). Prosperity without growth: Economics for a finite planet. London: Routledge/ Earthscan.

Kalamar, A. (2013). Sharewashing is the new greenwashing. Retrieved February 2, 2015, from http://www.opednews.com/articles/Sharewashing-is-the-New-Gr-by-AnthonyKalamar-130513-834.html

Kaswan, M. J. (2014). Developing democracy: Cooperatives and democratic theory. International Journal of Urban Sustainable Development, 6(1), 190-205. doi:10.1080/19463138.2014.9510 48.

Kawano, E. (2009). Into the light: The emerging solidarity economy movement in the United States, Cayapa, 10: 50-64. Mérida, Venezuela: Centro Internacional de Investigación e Información sobre la Economía Pública Social y Cooperativa.

Kawano, E. (2013). Social solidarity economy: Toward convergence across continental divides. UNRISD News \& Views. Retrieved March 3, 2015, from http://www.unrisd.org/unrisd/website/newsview.nsf/\%28httpNews\%29/F1E9214CF8EA21A8C1257B1E003B4F65?OpenDocu ment

Kawano, E., Masterson, T. N., \& Teller-Elsberg, J. (Eds.). (2009). Solidarity economy I: Building alternatives for people and planet. Amherst: Center for Popular Economics.

Laville, J.-L. (Ed.). (1994). L'économie solidaire: une perspective internationale. Paris: Desclée de Brouwer.

Laville, J.-L. (2003). A new European socioeconomic perspective. Review of Social Economy, $L X(3), 389-405$.

Laville, J. -L. (2011). What is the third sector? From the non-profit sector to the social and solidarity economy: Theoretical debates and European reality (EMES European Research Network Working Paper 11/01).

Laville, J.-L., \& Cattani, A. D. (Eds.). (2006). Dictionnaire de l'autre économie. Paris: Folio actuel.

Lemaître, A., \& Helmsing, A. H. J. B. (2012). Solidarity economy in Brazil: Movement, discourse and practice analysis through a Polanyian understanding of the economy. Journal of International Development, 24, 745-762.

Levine, S. H. (2003). Comparing products and production in ecological and industrial systems. Journal of Industrial Ecology, 7(2), 33-42.

Lietaer, B. (2004). Complementary currencies in Japan today: History, originality and relevance. International Journal for Community Currency Research, 8, 1-23.

Lietaer, B., \& Kennedy, M. (2008). Monnais Régionales: De nouvelles voies vers une prosperité durable. Paris: Charles Léopold Mayer.

Lowen, M. (2012). Greece bartering system popular in Volos. BBC Europe, News. Retrieved February 3, 2015, from http://www.bbc.com/news/world-europe-17680904

Massard, G. (2015, January 20). Personal Interview by M. Sahakian. Geneva

Massard, G., Jacquat, O., \& Zürcher, D. (2014). International survey on ecoinnovation parks. Learning from experiences on the spatial dimension of eco-innovation. Environmental studies. Bern: Federal Office for the Environment and the ERANET ECO-INNOVERA.

McMillan, R. (2014). The Fierce battle for the Soul of Bitcoin. WIRED Business. Retrieved February 23, 2015, from http://www.wired.com/2014/03/what-is-bitcoin 
Okuno, S. (2004). Enhancing sustainable communities with local currencies: Eco-money experiment in Japan. In World forum proceedings of the International Research Foundation for Development.

Opoku, H. N. (2004). Policy implications of industrial ecology conceptions. Business Strategy and the Environment, 13, 320-333.

Ostrom, E. (2001/1990). Governing the commons: The evolution of institutions for collective action. Cambridge: Cambridge University Press.

Poggioli, S. (2011). Modern Greeks return to ancient system of barter. Retrieved Nov 8, 2013, from http://www.npr.org/2011/11/29/142908549/ modern-greeks-return-to-ancient-system-of-barter

Polanyi, K. (1957). The economy as instituted process. In K. Polanyi, C. M. Arensberg, \& H. W. Pearson (Eds.), Trade and market in the early empires (pp. 243-270). Glencoe: Free Press.

Polanyi, K. (2001). The great transformation: The political and economic origins of our time (1944). Boston: Beacon.

Prades, J. (2013). Comment résister au capitalisme? Tous en coopératives! Aubiet: Le vent se lève.

Price, R., Thornton, S., \& Nelson, S. (2007). The social cost of carbon and the shadow price of carbon: What they are, how to use them in economic appraisal in the UK (Defra evidence and analysis series). London: Department for Environment, Food and Rural Affairs.

Ransom, D., \& Baird, V. (Eds.). (2010). People first economics. Oxford: New Internationalist Publications.

Rifkin, J. (2014). The zero marginal cost society: The internet of things, the collaborative commons, and the eclipse of capitalism. New York/London: Palgrave Macmillan.

Sahakian, M. (2014). Complementary currencies, what opportunities for sustainable consumption in times of crisis and beyond? Sustainability: Science. Practice \& Policy, 10(1), 4-13.

Sahakian, M. D., \& Dunand, C. (2015). The social and solidarity economy towards greater 'sustainability': Learning across contexts and cultures, from Geneva to Manila. Community Development Journal, 50, 403-417.

Sahakian, M., \& Servet, J.-M. (in press). Separating the wheat from the chaff: Sharing versus selfinterest in crowdfunding. In D. Assadi (Ed.), Strategic approaches to crowdfunding. Hershey: IGI Global.

Sahakian, M., \& Steinberger, J. K. (2011). Energy reduction through a deeper understanding of household consumption: Staying cool in metro manila. Journal of Industrial Ecology, 15(1), $31-48$.

Sarkis, J. (Ed.). (2001). Greener manufacturing and operations: From design to delivery and back. Sheffield: Greenleaf.

Satgar, V. (Ed.). (2014). The solidarity economy alternative: Emerging theory and practice. Pietermaritzburg: University of KwaZulu-Natal Press.

Scanlon, K., Lloyd, S., Gray, G., Francis, R., \& LaPuma, P. (2015). An approach to integrating occupational safety and health into life cycle assessment: Development and application of work environment characterization factors. Journal of Industrial Ecology, 19(1), 27-37.

Schor, J. B., \& Thompson, C. J. (Eds.). (2014). Sustainable lifestyles and the quest for plenitude case studies of the new economy. New Haven: Yale University Press.

Servet, J.-M. (2006). Towards an alternative economy: Reconsidering the market, money and value. In C. Hann \& K. Hart (Eds.), Market and society: The great transformation today. Cambridge: Cambridge University Press.

Servet, J.-M. (2007). Le principe de la réciprocité chez Karl Polanyi, contribution à une définition de l'économie solidaire. Revue Tiers Monde, 2(190), 255-273.

Servet, J. -M. (2014). De nouvelles formes de partage: la solidarité au delà de l'économie collaborative. Veblen Institute. Retrieved March 3, 2015, from http://www.veblen-institute.org/ spip.php?page=imprimer\&lang=fr\&id_article $=190$

Seyfang, G. (2007). Personal carbon trading: Lessons from complementary currencies. CSERGE working paper ECM 07-01. Retrieved March 3, 2015, from http://cserge.ac.uk/sites/default/ files/ecm_2007_01.pdf 
Singer, P. (2002). Introduçaon à Economia Solidaria. Sao Paolo: Fondacion Perseu Editora.

Studer, T. (2006). WIR and the Swiss National Economy. Rohnert Park: Lulu Online Publishing.

Swaton, S. (2011). Une entreprise peut-elle être "sociale" dans une économie de marché? Charmey: Editions de l'Hèbe.

Swaton, S., \& Baranzini, L. (2013). Définir la nouvelle économie sociale par les critères plutôt que par les statuts? Une analyse théorique à partir des critères retenus en Suisse par Après-Ge. Cahiers du CIRTES, Presses Universitaires de Louvain, 9, 53-68.

Swaton, S., \& Sahakian, M. (2014). The social and solidarity economy: What is it? SCORAI workshop on inter- trans-disciplinarity. Lausanne.

The Economist. (2005, December 20). Frequent-flyer miles: Funny money. Retrieved February 23, 2015, from http://www.economist.com/node/5323615

UNEP. (2009). Guidelines for social life cycle assessments of products. B. M. Catherine Benoit. Paris: United Nations Environment Programme.

UNEP. (2011). Towards a GREEN economy. Pathways to sustainable development and poverty eradication. A Synthesis for Policy Makers. Retrieved March 3, 2015, from http://www.unep. org/greeneconomy/Portals/88/documents/ger/GER_synthesis_en.pdf

Victor, P. A. (2008). Managing without growth: Slower by design, not disaster. Cheltenham/ Northampton: Edward Elgar.

Yuan, Z., Bi, J., \& Moriguichi, Y. (2006). The circular economy: A new development strategy in China. Journal of Industrial Ecology, 10(1-2), 4-8. 